\title{
Changes in acceleration rate of chloride ions depending on climatic conditions. Influence of rain
}

\author{
F. Corvo*, C. Arroyave**, M. Autié*, J. Minotas ${ }^{* * *}$, J. Balmaseda*, \\ J. Delgado** and C. Haces*
}

\begin{abstract}
Mild steel, copper and aluminium samples were exposed outdoors in two atmospheric test stations located in Havana, Cuba and Medellín, Colombia. Two parallel group of samples were formed, one for each station. They were submitted to accelerated outdoor test by intermittent spraying of a salt solution (SCAB test) according to ISO 11474:98, receiving also the influence of the open atmosphere. The acceleration of corrosion rate of the three metals caused by the presence of chloride ions in both stations was determined. As expected, steel shows the higher corrosion rate and acceleration by chlorides, particularly at Cuban corrosion station. A remarkable difference in the acceleration rate of chloride ions for mild steel and copper between Cuban and Colombian acceleration rate of chloride ions of steel and copper. Steel corrosion products were analysed by Mossbauer Spectroscopy. Water absorption was also studied. The presence of magnetite, goethite and other Iron compounds was determined.
\end{abstract}

Keywords Chloride ions. Mild steel. Copper. Aluminium. Water adsoption.

\section{Cambios en la velocidad de aceleración provocada por los iones cloruros en dependencia de las condiciones climáticas. Influencia de la lluvia}

Resumen Probetas de acero de bajo carbono, cobre y aluminio se expusieron a la intemperie en dos estaciones de ensayo localizadas en la Habana, Cuba y Medellín, Colombia. Se formaron dos grupos paralelos de probetas, tomándose uno para cada estación. Ambos grupos fueron sometidos a ensayos acelerados a la intemperie mediante la aplicacion de una niebla salina (SCAB TEST) de acuerdo a la Norma ISO 11474:98, recibiendo también la influencia de la atmósfera abierta. Se determinó la aceleración de la velocidad de corrosión de los tres metales causada por la presencia de iones cloruro en ambas estaciones. Como era de esperar, el acero muestra la mayor velocidad de corrosión y aceleración por los iones cloruro, particularmente en la estación de ensayos cubana. Se determinó una notable diferencia en la velocidad de aceleración provocada por los cloruros para el acero de bajo carbono y el cobre entre las estaciones cubana y colombiana. La influencia de la lluvia parece muy importante en determinar la velocidad de aceleración de los iones cloruro sobre el acero y el cobre. Los productos de corrosión fueron analizados por Espectroscopia Mossbauer. La adsorción del agua fue también estudiada. Se determinó la presencia de magnetita, goetita y otros compuestos de hierro en los productos de corrosión.

Palabras clave Iones cloruro. Acero de bajo carbono. Cobre. Aluminio. Adsorción de agua.

\section{INTRODUCTION}

Chloride ions are one of the most important natural contaminants having influence on corrosion of metals. However, its role may change depending on climate. A very humid climate can cause a fast dissolution of chloride ions and diminish its role in the acceleration of corrosion rate. A different acceleration mechanism has been reported for chloride ions between Eastern and Western Caribbean ${ }^{[1]}$.

In a single climate the influence of rain could change the acceleration of chloride ions on metal corrosion. Differences between rainy and dry

(*) Chemistry Division. National Centre for Scientific Research (CNIC). P.O. Box 6421. Havana (Cuba).

$\left(^{* *}\right)$ Corrosion Group. Faculty of Engineering. Antioquia University. 
seasons could be important in determining the acceleration cause by chloride ions. The electrochemical mechanism of corrosion by chloride ions do not changes, but the time and the concentration during which chloride ions acts on the metallic surface may appreciable change depending on climatic conditions and the nature of corrosion products.

Atmospheric corrosion occurs in an alternating growing and decreasing layer of electrolyte, which is usually very thin. In the case of existing corrosion products at metal-atmosphere interface, the sorption properties of these products and salts (usually hygroscopic) deposited or formed by corrosion determine the possibilities of presence of superficial wetness ${ }^{[2]}$. The amount of water on the corroding surface is of great importance for the corrosion rate.

Results from a very limited number of runoff studies are available in the literature ${ }^{[3]}$. The understanding of air pollution effects on metallic corrosion has advanced considerably over the past several decades, there have been very few attempts to investigate the relation between precipitation features and metal damage. Besides the chemical composition of rainwater, the physical characteristics of precipitation (rainfall rate and amount, frequency and length of dry and wet events) also play a role in the corrosion process. It is reported ${ }^{[4]}$ that the time evolution of chloride ion concentration in the steel runoff is approximately twice that presented in copper runoffs. The high values of steel over those from rainwater, suggest that chloride participate in the metal attack without forming corrosion products.

To study the rol of rainfall and other parameters in the corrosion acceleration of chloride ions is the main objective of the present paper. A cooperation between Corrosion Group from Antioquia University, Medellin, Colombia, and Corrosion Department, National Centre for Scientific Research, Havana, Cuba has made possible to obtain and process data at the same time in test stations of both countries having climatic differences.

\section{EXPERIMENTAL PROCEDURE}

Samples of AISI 1019 carbon steel, copper and aluminium were exposed at CNIC's and Antioquia University corrosion stations at Havana, Cuba, and Medellín, Colombia. The main characteristics of pollution of these stations are shown on table I. It can be observed that CNIC's corrosion station is slightly more polluted than Antioquia's.

Samples were exposed facing south at $45^{\circ}$ to the horizontal. Samples were submitted to a salt spray twice a week according to ISO $11474^{[5]}$. The average quantity of $3 \% \mathrm{NaCl}$ solution added to each sample was measured. It was about $2.37 \mathrm{ml}$ by sample, equivalent to a chloride deposition rate of about $850 \mathrm{mg} / \mathrm{m}^{2} \mathrm{~d}$.

Weight loss of steel, copper and aluminium was evaluated for different exposure times (See Table II and chapter II). Samples size was $100 \mathrm{~mm} \times$ $150 \mathrm{~mm} \times 1-2 \mathrm{~mm}$. Chloride and $\mathrm{SO}_{2}$ deposition rate were evaluated monthly. The determination was carried out by the wet candle method in the case of chloride ions and by alkaline sulfhation plates in the case of $\mathrm{SO}_{2}$. Time of wetness was calculated using temperature-humidity data obtained from meteorological stations. Time of wetness at different intervals of temperature and relative humidity was calculated. Rain data was also obtained from meteorological stations.

Adsoption isotherms were determined by the liquid-volumetric method ${ }^{[6]}$. Rust samples were activated at 300 and $423 \mathrm{~K}$ and $0.13 \mathrm{~Pa}$ during $15 \mathrm{~h}$. Water was supplied in quantities of $0.174 \mathrm{mmol}$ every time, waiting for the necessary time up to the establishment of the equilibrium. Experimental isotherms were fitted to the Dubinin model. Based on this model maximum adsorption, microporous volume and characteristics energies were calculated.

Mossbauer spectra at room temperature of rust samples were obtained in order to determine phase composition of corrosion products.

Table I. Main characteristics of pollution of corrosion stations (chloride and sulphur compounds deposition rate). Data corresponds to period May-December/99

Tabla I. Características generales de la contaminación en las estaciones de corrosión (velocidades de deposición de cloruros y compuestos del azufre). Datos correspondientes al período mayo-diciembre/99

\begin{tabular}{|c|c|c|c|c|c|c|}
\hline \multirow[t]{2}{*}{ Station } & \multicolumn{3}{|c|}{$\begin{array}{c}\text { Chloride } \\
\text { Deposition Rate } \\
\left(\mathrm{mg} / \mathrm{m}^{2} \mathrm{~d}\right)\end{array}$} & \multicolumn{3}{|c|}{$\begin{array}{l}\text { Sulphur comp. } \\
\text { Deposition Rate } \\
\left(\mathrm{mg} / \mathrm{m}^{2} \mathrm{~d}\right)\end{array}$} \\
\hline & Ave. & Min. & Max. & Ave. & Min. & Max. \\
\hline CNIC & 20.1 & 7.7 & 77.6 & 20.9 & 16.8 & 25.0 \\
\hline Antioquia & 6.5 & 1.8 & 22.9 & 9.2 & 1.8 & 21.4 \\
\hline
\end{tabular}


Table II. Weight loss $\left(\mathrm{g} / \mathrm{m}^{2}\right)$ for steel, copper and aluminium submitted to salt spray and exposed at Antioquia and CNIC stations

Tabla II. Pérdidas de peso $\left(\mathrm{g} / \mathrm{m}^{2}\right)$ del acero, cobre y aluminio sometidos a niebla salina y expuestos en las estaciones de Antioquia y el CNIC

\begin{tabular}{cccccccc}
\hline \multirow{2}{*}{ Time (months) } & \multicolumn{3}{c}{ Antioquia } & & \multicolumn{3}{c}{ CNIC } \\
\cline { 2 - 4 } \cline { 6 - 8 } & Steel & Copper & Aluminium & & Steel & Copper & Aluminium \\
\hline 1 & 115.8 & 2.9 & 0.4 & & 280.7 & - & - \\
1 & 152.6 & 2.7 & 0.3 & & 280.3 & - & - \\
1 & 138.1 & 2.9 & 0.6 & & 304.5 & - & - \\
3 & 350.0 & 6.8 & 2.2 & & 1142.7 & 13.9 & - \\
3 & 423.7 & 6.7 & 1.6 & & 1513.6 & 12.7 & - \\
3 & 307.9 & 6.3 & 1.1 & & 1599.9 & 12.7 & 1.5 \\
6 & 496.2 & 11.1 & 1.6 & & 3827.9 & 20.7 & 1.5 \\
6 & 531.5 & 10.8 & 2.1 & & 3845.1 & 21.6 & 1.5 \\
6 & 588.5 & 11.3 & 1.5 & & 3809.5 & 20.6 & \\
\hline
\end{tabular}

\section{RESULTS}

\subsection{Corrosion of metals at CNIC's and Antio- quia stations}

The influence of chloride ions at Antioquia and CNIC corrosion station was studied by submitting samples of steel, copper and aluminium to salt spray during exposure to the open atmosphere. From tables II and III it can be observed that up to 6 months of exposure, the acceleration caused by chloride ions added in equal quantity is notably higher at CNIC's station for steel and copper. In the case of steel, it increases with time. Aluminium behaves in a different way, although there is only data corresponding to 6 months, because there is more acceleration at Antioquia than at CNIC. It could be due, perhaps, to a higher cleansing effect of rain in Cuba, causing a more effective elimination of chloride from the aluminium surface. As a passive metal aluminium is much more sensible to surface contamination than steel and copper.

Table III. Average relation Weight Loss Antioquia/Weight Loss CNIC for steel, copper and aluminium at different exposure times

Tabla III. Relación media Pérdida de peso Antioquia/Pérdida de peso CNIC para el acero, cobre y aluminio a diferentes tiempos de exposición

\begin{tabular}{cccc}
\hline \multirow{2}{*}{$\begin{array}{c}\text { Time } \\
\text { (months) }\end{array}$} & \multicolumn{3}{c}{ Antioquia/CNIC } \\
\cline { 2 - 4 } & Steel & Copper & Aluminium \\
\hline 1 & 0.47 & - & - \\
3 & 0.23 & 0.5 & - \\
6 & 0.14 & 0.53 & 1.7 \\
\hline
\end{tabular}

\subsection{Influence of environmental parameters on corrosion at CNIC's corrosion station}

\subsubsection{Influence of rain}

Every sample submitted to the experiment according to ISO 11474 receives about $850 \mathrm{mg} / \mathrm{m}^{2} \mathrm{~d}$ of chloride ions. As samples are exposed to the open atmosphere, chloride deposition rate may change according to climatic conditions. Undoubtedly, rain diminishes chloride surface concentration, so it is possible that the acceleration rate caused by chloride ions may diminish when rain quantity increases at constant exposure time.

As can be seen from table IV, the influence of rain quantity is significant in changes of corrosion rate of steel and copper; however, the influence is different. In the case of steel an increase in rain quantity causes a lower corrosion $(b<0)$ while for copper rain increases corrosion rate $(b>0)$. This different behavior could be due to the solubility of corrosion products, because iron chlorides are much more soluble than copper chlorides. Although the above regression equations are very significant, they only explain less than $50 \%$ of the cases. It means that there are other factors having influence on metals corrosion. It got to be taken into account that for small times of exposure there is difficult to obtain good correlation coefficients ${ }^{[7]}$.

The term $\mathrm{K}_{\mathrm{Cl}}-\mathrm{K}_{\mathrm{noCl}}$ has been considered as the acceleration rate, because it is the difference between the corrosion of samples exposed in the natural atmosphere under the influence of a salt spray and those without this influence. 
Table IV. Regression equations obtained between steel and copper weight loss and rain quantity $(\mathrm{mm})$.

$(y=a+b \log x)$. Time of exposure: 1 months for steel and 3 months for copper

Tabla IV. Ecuaciones de regresión obtenidas entre la pérdida de peso del acero y el cobre y la cantidad de lluvia en $\mathrm{mm}(y=a+b \log x)$. Tiempo de exposición: 1 mes para el acero y 3 meses para el cobre

\begin{tabular}{lrccrc}
\hline Metal $(\mathbf{y})$ & $\mathbf{a}$ & $\mathbf{b}$ & $\mathbf{r}$ & $\mathbf{r}^{2}(\%)$ & Significance \\
\hline Steel & & & & & \\
$\mathrm{K}_{\mathrm{Cl}}$ & 372.4 & -43.7 & -0.67 & 44.9 & $99 \%$ \\
$\mathrm{~K}_{\text {noCl }}$ & 45.6 & -1.25 & -0.13 & 1.8 & $90 \%$ \\
$\mathrm{~K}_{\mathrm{Cl}}-\mathrm{K}_{\text {noCl }}$ & 326.8 & -42.5 & -0.67 & 44.6 & $99 \%$ \\
Copper & & & & & \\
$\mathrm{K}_{\mathrm{Cl}}$ & -955.3 & 358.1 & 0.50 & 25.5 & $99 \%$ \\
$\mathrm{~K}_{\text {noCl }}$ & -18.7 & 20.4 & 0.58 & 33.8 & $99 \%$ \\
$\mathrm{~K}_{\mathrm{Cl}}-\mathrm{K}_{\text {noCl }}$ & -936.5 & 364.7 & 0.50 & 24.8 & $99 \%$ \\
\hline
\end{tabular}

$K_{\mathrm{Cl}}=$ Weight loss $\left(\mathrm{g} / \mathrm{m}^{2}\right)$ for samples with application of salt spray $K_{\text {noCl }}=$ Weight loss $\left(\mathrm{g} / \mathrm{m}^{2}\right)$ for samples without application of salt spray

$R(\mathrm{~mm})=\operatorname{Rain}(\mathrm{mm})$

$a=$ Intercept of the regression equation

$b=$ Hape of the regression equation

$r=$ Correlation coefficient

$r^{2}=$ Percent of variables explanation

\subsubsection{Behaviour at longer times}

Data corresponding to 1, 3 and 6 months of exposure of steel at CNIC's station were processed and the following regression equations were obtained:

$$
\begin{gathered}
K_{\mathrm{Cl}}=-614.8+18.8 \mathrm{~K}_{\mathrm{noCl}} \\
R^{2}=74.0 \%
\end{gathered}
$$

This regression equation shows that there is a good agreement between steel corrosion rate submitted to a saline spray and without it exposed on the same atmospheric conditions. A similar behaviour is determined for aluminium at 6 and 12 months of exposure and a different one for copper at 3 and 6 months of exposure.

Aluminium:

$$
\begin{gathered}
K_{\mathrm{Cl}}=-1.16+14.6 \mathrm{~K}_{\mathrm{noCl}} \\
R^{2}=80.5 \% \\
\text { Copper } \\
\mathrm{K}_{\mathrm{Cl}}=11.98+0.55 \mathrm{~K}_{\mathrm{noCl}} \\
\mathrm{R}^{2}=4.8 \%
\end{gathered}
$$

There is almost no relationship between copper weight loss in addition of chloride ions and without it. An analysis of the data set shows that weight loss of samples without addition of chlorides appreciable changes, while in the presence of these anions weight loss is almost independent of changes on climatic season.

\subsubsection{Influence of time of wetness}

Previous results have shown that time of wetness in Cuban conditions could be divided into three main categories ${ }^{[8]}$, time at $80-100 \%$ relative humidity and temperature in the range $5-25^{\circ} \mathrm{C}$, time at $80-100 \%$ relative humidity and temperature in the range $25-35^{\circ} \mathrm{C}$ and time of rain. In this case the days of rain has been considered as time of rain.

As can be seen on table $V$, a different behaviour on the influence of the categories of time of wetness can be observed for steel and copper. In the case of steel, a higher influence of time of wetness at temperature in the range $5-25^{\circ} \mathrm{C}$ (coefficient $b$ ) respecting to $\tau_{25-35}$ is obtained. The role of rain changes in presence of the salt spray. Weight loss increases with days of rain in presence of high salinity. It is not opposed to the above results obtained for one month period because in this case it is studied the influence of rain at longer and not constant time of exposure.

In the case of copper, the parameter with higher influence on corrosion is time of rain. A negative sign affecting coefficients $\mathrm{b}$ and $\mathrm{c}$ is not logic, because corrosion should always occur at relative humidity $80-100 \%$ and temperature intervals $5-25^{\circ} \mathrm{C}$ and $25-35^{\circ} \mathrm{C}$. This result could be due to the influence of other variables not taken into account in the regression equations or to the existence of a given correlation between variables considered as independent.

\subsection{Corrosion products phase characterization}

Mossbauer and IR Spectra shows the presence of Magnetite and Goethite as main phases in corrosion products of steel submitted to salt spray in natural conditions after 6 months of exposure. A paramagnetic phase, still unidentified is also reported according to the results of Mossbauer Spectra (See Table VI)

Water adsorption of corrosion products. The Dubinin Theory ${ }^{[9}$ and 10$]$ (Volumetric Microporous Fitting) was used to study activated carbon, but at 
Table V. Regression equations obtained between steel and copper weight loss and different categories of time of wetness ( $K=a+b \tau_{5-25}+c \tau_{25-35}+d$ DLluv). Time of exposure: 1-3-6 months for steel and 3-6 months for copper

Tabla V. Ecuaciones de regresión obtenidas entre la pérdida de peso del acero y el cobre y diferentes categorías de tiempo de humectación ( $k=a+b \tau_{5-25}+c \tau_{25-35}+d$ DLluv). Tiempo de exposición: 1-3-6 meses para acero y 3-6 meses para cobre

\begin{tabular}{lcccccc}
\hline \multicolumn{1}{c}{ Metal(y) } & $\mathbf{a}$ & $\mathbf{b}$ & $\mathbf{c}$ & DLLuv & $\mathbf{r}^{2}(\%)$ & Significance \\
\hline Steel & & & & & & \\
$\mathrm{K}_{\mathrm{Cl}}$ & -338.6 & 1.11 & 0.26 & 31.6 & 89.6 & $99 \%$ \\
$\mathrm{~K}_{\mathrm{noCl}}$ & 6.56 & 0.16 & 0.03 & -0.54 & 94.3 & $99 \%$ \\
$\mathrm{~K}_{\mathrm{Cl}}-\mathrm{K}_{\text {noCl }}$ & -345.1 & 0.38 & 0.23 & 32.1 & 88.7 & $99 \%$ \\
Copper & & & & & & \\
$\mathrm{K}_{\mathrm{Cl}}$ & 15.56 & -0.02 & -0.01 & 0.51 & 98.7 & $99 \%$ \\
$\mathrm{~K}_{\text {noCl }}$ & -7.02 & 0.02 & 0.02 & -0.5 & 97.3 & $99 \%$ \\
$\mathrm{~K}_{\mathrm{Cl}}-\mathrm{K}_{\text {noCl }}$ & 22.59 & -0.04 & -0.03 & 1.03 & 97.5 & $99 \%$ \\
\hline
\end{tabular}

$K_{\mathrm{Cl}}=$ Weight loss $\left(\mathrm{g} / \mathrm{m}^{2}\right)$ for samples with application of salt spray $K_{\text {noCl }}=$ Weight loss $\left(\mathrm{g} / \mathrm{m}^{2}\right)$ for samples without application of salt spray DLLuv $=$ Days of rain during the period of exposure

the present time it is recommended in general for the determination of microporous volume.

The adsorption isotherms obtained show that activated rusts have a heterogeneous porous structure due to the presence of two homogeneous zones. In this case adsorption is described by the Dubinin-Radushkievich equation. Samples without chloride addition show higher maximum adsorption and porous volume than those with addition of chlorides (see Table VII). However, the characteristic energy of the samples with chloride addition is higher. It means that water is stronger linked due to the hydration heat of the chlorides.

Maximum adsorption in the sample without chloride addition is higher at $300^{\circ} \mathrm{C}$ activation temperature, showing that desorption is easier at that temperature. Relatively lower values of the characteristic energies show that water adsorption has a physical link, but it should be noted a marked difference between the energies of the second zone, higher in more than $70 \%$ in the sample with chloride addition, so this second zone has porous radii significantly smaller than sample without chlorides, showing that metal corrosion in

Table VII. Activation temperature-Ta $\left({ }^{\circ} \mathrm{K}\right)$, maximum adsorption-Am $(\mathrm{mmol} / \mathrm{g})$, microporous volume $-V p$ $\left(\mathrm{cm}^{3} / \mathrm{g}\right)$ and characteristic energy $-E c(\mathrm{~kJ} / \mathrm{mol})$ of water adsorption in rust formed in the atmosphere after six month of exposure

Tabla VII. Temperatura de activación-Ta $\left({ }^{\circ} \mathrm{K}\right)$, adsorción máxima-Am (mmol/g), volumen de microporos $-V_{p}$ $\left(\mathrm{cm}^{3} / \mathrm{g}\right)$ y energía característica $-E_{c}(\mathrm{~kJ} / \mathrm{mol})$ de absorción de agua en óxido formado en la atmósfera después de seis meses de exposición

\begin{tabular}{ccccc}
\hline \multicolumn{1}{c}{ Rust } & Ta & Am & Vp & Ec \\
\hline \multirow{4}{*}{ Chloride addition } & 300 & 0.68 & 0.012 & 4.42 \\
& 423 & 1.34 & 0.024 & 7.39 \\
Without chloride addition & 423 & 1.70 & 0.031 & 5.29 \\
& 300 & 0.91 & 0.016 & 4.58 \\
& 423 & 1.46 & 0.026 & 6.93 \\
& 423 & 1.98 & 0.036 & 3.08 \\
\hline
\end{tabular}

Table VI. Subspectra parameters fitted to the Spectra of rust with addition of chloride ions

Tabla VI. Parámetros del subespectro ajustados al espectro del óxido con adición de iones cloruro

\begin{tabular}{lcccc}
\hline \multicolumn{1}{c}{ Phase } & $\delta, \mathrm{mm} / \mathrm{s}$ & $\Delta, \mathrm{mm} / \mathrm{s}$ & $\mathrm{H}, \mathbf{T}$ & $\mathrm{A}, \%$ \\
\hline Paramagnetic & $0.358 \pm 0.003$ & $0.600 \pm 0.006$ & - & 10.80 \\
Magnetite & $0.304 \pm 0.002$ & $-0.011 \pm 0.004$ & $48.86 \pm 0.02$ & 38.20 \\
Goethite & $0.43 \pm 0.01$ & $0.02 \pm 0.02$ & $45.3 \pm 0.1$ & 23.48 \\
\hline
\end{tabular}

$\delta, \mathrm{mm} / \mathrm{s}=$ Isometric shift

$\Delta, \mathrm{mm} / \mathrm{s}=$ Quadrupole splitting

$H, T=$ Magnetic field 
the presence of chlorides should be higher because water desorption is more difficult.

The existence of two zones having different porous radii suggest that first there are formed small porous due to the action of aggressive agents $\left(\mathrm{O}_{2}, \mathrm{H}_{2} \mathrm{O}\right.$, i.e. $)$ and afterwards, secondary adsorption centres are formed with higher radii.

\section{CONCLUSIONS}

The acceleration rate caused by chloride ions is higher in Cuban climate than in Antioquia for steel and copper, but lower for aluminium.

The influence of rain quantity is significant in changes of corrosion rate of steel and copper in the atmosphere in the presence of chlorides; however, the behaviour of these two metals is not the same respecting this parameter.

Water adsorption in rust is stronger in the presence of chlorides making desorption more difficult. It increases corrosion rate.

\section{REFERENCES}

[1] F. Corvo, C. Haces, N. Betancourt, L. Maldonado, L. VELEVA, M. ECHEVERRIA, O.T. de RinCÓN and A. RinCON, Corros. Sci. 395 (1997) 823-833.

[2] F. Corvo, A.R. Mendoza, M. Autie and N. Betancourt, Corros. Sci. 394 (1997)1-6.

[3] I.O. Wallinder and C. LeYGraf, Proc. $14^{\text {th }}$ Inter. Congr., September 27 to October 1, 1999, Cape Town, South Africa, paper 172.2

[4] J.M. Costa, J. Lorente, M. Vilarasa and B. Codina, Proc. $14^{\text {th }}$ Inter. Corros. Congr., September 27 to October 1, 1999, Cape Town, Sout Africa, paper 36.1.

[5] ISO 11474, Corrosion of metals and alloys-Corrosion tests in artificial atmosphere-Accelerated outdoor by intermittent spraying of a salt solution (SCAB test).

[6] I.A. GUERAsImOV, Curso de Química Física, Editorial MIR, Moscú, 1971, Cap. XVI.

[7] F. Corvo, N. Betancourt and A. Mendoza, Corros. Sci. 372 (1995) 1.889-1.901.

[8] A.R. MEndozA and F. Convo, Corros. Sci. 41 (1999) 75-86

[9] E.D. ZaverinA and M.M. Dubinin, Zh. Fiz. Jimii 13 (1939) 151-162.

[10] M.M. Dubinin, E.D. ZAVERINA and L.V. RADUSHKIEVICH, Zh. Fiz. Jimii 21 (1947) 1.351-1.362. 